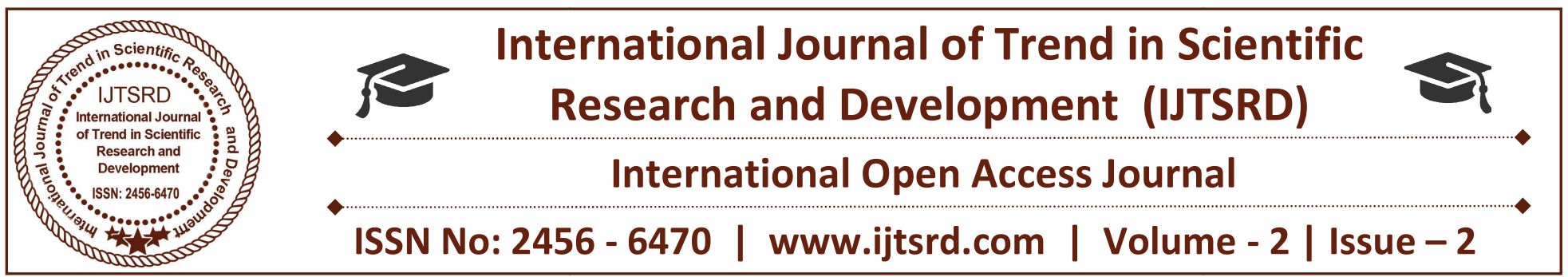

\title{
A Study on Enhancing Employability Skills of Graduates in India
}

\section{P. Vanitha}

Assistant Professor in Business Administration (PG), K.S.R College of Arts and Science (Autonomous), Tiruchengode, Tamil Nadu, India

\author{
Dr. A. T. Jaganathan
}

Head \& Associate Professor in Business

Administration (UG\&PG), K.S.R College of Arts and Science (Autonomous), Tiruchengode, Tamil Nadu

\section{ABSTRACT}

The purpose of this study was to identify the employability skills that employers perceive to be important for entry-level graduates and the skills set required for sustainable employability of graduates in India. In most of the Indian colleges, students are from different academic backgrounds coming from different places having different mother tongues. So, there is a need to provide them a common platform to make them competent enough to face the real challenges of today's corporate world. English is the language which can remove the lingual difference among them and give them a common medium to communicate. Employers are often looking for skills that go beyond qualifications and experience. Each employer has different perceptions and expectations toward graduate skills. According to many research findings the students with skills like positive attitude, effective communication, problem solving, time management, team spirit, self-confidence, handling criticism, flexibility, etc which are also known as soft skills as a whole, have much more better chances of survival in the tough corporate world compared to the students who are lacking in the soft skills. Employability skills are very essential in the current global job market. Skill shortage remains one of the major constraints to continued growth of the Indian economy.

Keywords: Education, Employability skills, Skill shortage, Soft skills, Global job market

\section{Introduction}

Graduate employability skills have become one of the most important topics on the higher education agenda in this current era in India. Today's employers are increasingly focusing on hiring graduates who possess a broader skill-set than in the past and also the workforce is characterized by change and increasing competition for jobs. So, it is important for educational programs, to be aware of the qualities that are valued by employers in the industry and provide the same for graduates.

Universities have the responsibility to design and implement programs that are appropriate to the missions and goals to supply the workforce that are relevant to the needs of employers. It becomes the responsibility of universities to provide graduates with knowledge in the professional field with intellectual skills and ability to apply theory to practical situations. Other generic university skills as identified by the Malaysian qualification frameworks such as the ability to communicate, possession of attitudes and values of responsible citizen are other areas that is expected to be developed during the course of study (2008).

Employers in any industrial sector emphasize the need for employees with certain foundational skills such as teamwork, problem solving, work ethic and integrity. Graduate employability is a key issue for Higher Education because employers don't always spell out 
the exact need or expectation of employability skill set from the employees which makes it difficult for prospective employees and educators to know exactly what it takes to be ready to succeed in any career path in any industry.

\section{What are employability skills?}

'Employability skills are defined as skills required not only to gain employment, but also to progress within an enterprise so as to achieve one's potential and contribute successfully to enterprise strategic directions.' (DEST 2002a)

The concept of 'employability' has been defined as 'the ability of an individual to secure and sustain employment and progress within the workplace', recognizing that different types of employment have different 'employability' requirements (Belt et al.2010:1-5,UKCES 2010:2-3).

The definition of employability that underpins the work of the Higher Education Academy and ESECT is:

"A set of skills, knowledge and personal attributes that make an individual more likely to secure and be successful in their chosen occupation(s) to the benefit of themselves, the workforce, the community and the economy."

Employability skills are those skills, attributes, and behaviors, e.g., communication skills, problemsolving, organization, and planning, that bridge most disciplines, industries, and employing organizations. They have the greatest impact on the sustained, productive, successful employment of graduates (Cranmer, 2006; Gedye, Fender, \& Chalkey, 2004).

\section{Employers' perspective on employability skills of graduates}

For employers, recruiting the right people means finding people with the right skills and qualities to fulfill the given role and contribute to the success of the organization. Qualification is only the basic aspect to apply for the job, the employers often expect for skills that go beyond qualifications and experience. In order to be successful in the given role a person has to possess a mixed skill set. The mixed skill set includes hard skills and soft skills put together identified as employability skills.

The National Network has brought together the organizations that represent employers from major economic sectors, and they have identified the core set of fundamental skills that potential employees need in the workplace. This model serves as the foundation for all industries to map skill requirements and also it paves way for employees to understand the skills that all industries expect from them to be successful.

When it comes to the types of skills and knowledge that employers feel are most important to workplace success, large majorities of employers do feel that recent college graduates are not well prepared. This is particularly the case for applying knowledge and skills in real-world settings, critical thinking skills, and written and oral communication skills - areas in which fewer than three in 10 employers think that recent college graduates are well prepared. Yet even in the areas of ethical decision-making and working with others in teams, many employers do not give graduates high marks," the AACU report says.

India is one of the emerging markets in the world. India's change from an agrarian economy to an industrialized economy is lagging due to the shortage of skilled labor (The skill development landscape in India and implementing quality skill training, August 2010). Although the country has enough potential to deliver to the needs of the global talent market, there exists strong employability challenge for the graduates (Talent shortage survey, 2005) (Global talent risk-seven responses, 2011).

India's National Association of Software Services Companies estimates a potential shortfall of 500,000 technology professionals by 2010 (Talent shortage survey, 2005). There were several studies conducted in India to know the employability skills of the students. It is found that $75 \%$ of the Indian graduates are unemployable. (Talent shortage survey, 2005). The recent study conducted by World Bank (2011) points out that $64 \%$ of the employers says that they are only somewhat satisfied with the performance of the engineering graduates in India (Andreas Blom, 2011). Globally about $34 \%$ of the employers (Talent shortage survey, 2005) find it difficult to fill the talent gap and in India $67 \%$ of the employers find it difficult to find right talent in India (from both arts and science graduates). These results points out the need for proper awareness and training among the graduates to enhance their skills. 


\section{Importance of employability skills}

Insufficient supply of quality skills is one of the main impediments to further economic growth in India. The skill shortage is still one of the major constraints in most industries in India, (World Bank, 2009). As higher education has expanded, there has been increased emphasis on the skills that students learn during their time in higher education, beyond the knowledge, technical and academic skills related to their subject or indicated by their achieved class of degree (Mason, Williams and Cranmer 2006:2). Each employer has different perceptions and expectations toward graduate skills. One of the key reasons why many students invest in university education is to improve their employment prospects. However, whilst achievement of good academic qualifications is highly valued, it no longer appears sufficient to secure employment (Yorke, 2006). Additionally, employers expect students to have well developed employability skills, so that they can make an immediate contribution to the workplace when recruited (e.g. Confederation of British Industry, 2008).

The current trend of placing increased emphasis on graduate key skills therefore dictates that the higher education curriculum incorporates opportunities to develop such skills in conjunction with subjectspecific skills and knowledge. This should enhance applicants' potential for success in the recruitment process by producing 'business ready' graduates, able to make a dynamic start and rapidly adapt to change. Making the transition from higher education to the workforce is important (Crebert, Bates, Bell, CarolJoy and Cragnolini (2004)), stated that "the transition from university to employment often brings insecurity and unease". Despite widespread initiatives in employability skill provision in higher education, gaps between graduate workplace performance and employer expectations continue to persist (BIHECC, 2007; Helyer, 2011).

Importantly, graduate employability is multi-faceted and encompasses academic performance, career management skills, and labour market awareness (Rothwell \& Arnold, 2007), in addition to workplace learning (Billet, 2011), and personality theory (Rae, 2007). Skill development in higher education is however, considered a significant contributor to employability. It features prominently in models attempting to interpret and define the precise meaning of graduate employability.

\section{Employability skills expected by the employers}

From the employers' perceptions, they viewed that "applying theory into practice" is the most important skill that a graduate should have. A number of studies found that the expectations of employer on graduates in relation to university education appear to be strongly influenced by highly context-bound interpretations of desirable graduate capabilities, competencies and the professional attributes of a profession.

Both Marock (2008) \& Pool (2007) state that young adults entering the world of work in the 21 st century are required not only to be employable but also to sustain their employability during their careers by constant acquisition and updation of skills.

These skills were seen to have relevance to both entry-level and established employees. It was also recognized that the skills would be prioritized and adapted to suit various job-roles. The eight identified skills are:

- Communication skills that contribute to productive and harmonious relations between employees and customers

- Teamwork skills that contribute to productive working relationships and outcomes

- Problem solving skills that contribute to productive outcomes

- Self-management skills that contribute to employee satisfaction and growth

- Planning and organizing skills that contributes to long-term and short-term strategic planning

- Technology skills that contribute to effective execution of tasks

- Life-long learning skills that contribute to ongoing improvement and expansion in employee and company operations and outcomes

- Initiative and enterprise skills that contribute to innovative outcomes.

\section{Enhancing employability skills}

Enhancing the employability skills of university graduates is an area that is receiving much attention at present. Although there is much debate on what constitutes graduate employability skills, they are generally accepted as the knowledge, skills and attributes that graduates should have developed to be effective in the workplace, to the benefit of themselves, their employer and the wider economy. 
The most fundamental element of any effort to enhance employability of graduates is to understand what makes the graduates employable. The universities and HEI (Higher Education Institutions) have to take responsibility to identify the essential skill set needed for the graduates to be employable. So that the graduates can be trained according to the employers need.

Initial employment chances immediately after graduation are based on characteristics that are easily observable, such as the level and field of the study programme, the prestige of the HEI (Higher Education Institutions) from which the person graduated, grades, relevant work experience and international experience. It is therefore of great importance to understand in more detail which attributes employers are seeking from the graduates? when they recruit graduates? and which perceived attributes are likely to tip the scale in favor of one graduate compared to another?

Employability skills among the graduates can be enhanced by:

- Universities can work to develop employability skills in their students by providing academic staff with relevant support and resources, integrating these skills into curriculum and course design, providing students with work placements and exposure to professional settings and providing advice and guidance through career services.

- Connecting Higher Education and Industry

- Universities, industries and businesses can work more closely together to accomplish mutual goals.

- Universities and higher education institution can establish stronger ties to professional bodies and businesses in their locale

- Industries can work through professional bodies to help shape and inform up-to-date curriculum and course design

- Graduate Careers and Employment services can link students with employers and facilitate events which bring employers on campus

- Universities can invite business representatives to actively participate through formal structures and committees.

- Professional bodies can develop their own professional competency frameworks which can be used as tools to determine eligibility for membership and to assess for areas requiring professional development.

- Professional bodies should be the governors and protectors of curriculum. They should advocate for the profession as a whole'.

- Innovative learning, teaching and assessment methods which promote students' to understand and help them to engage in 'deep' learning which will enhance their employability.

- Involving employers in the education experience, for example, through placements, case studies, delivery of guest lectures, can help students appreciate the relevance of their course and learn how to apply theory and knowledge in practical ways in the workplace.

\section{Conclusion:}

Human resources, in terms of quality and quantity, are India's biggest assets. Employability skills are very vital for the success in the labor market in all sectors. Along with good technical understanding and subject knowledge, employers often outline a set of skills that they want from an employee. These skills are what they believe will equip the employee to carry out their role to the best of their ability. However, to capitalize fully on this opportunity and not face the possibility of a skills-shortage, it is essential to gear up the education system through innovative initiatives. This study provided areas where employers' perceived the areas that needed to be improved. The feedbacks can improve and increase the standard of education to create a better curriculum to fulfill the needs of students, employers, society and the whole nation.

\section{Reference:}

1. Smith Adam, "The Wealth of Nations", first published in 1776, reprinted in 2003.

2. Bianca Kubler, Peter Forbes, "Student Employability Profiles Engineering. Enhancing Student Employability", Coordination Team (ESECT), the Higher Education Academy, 2004

3. Hofstrand, R., "Getting all the skills employers want. Techniques: Making Education \&Career Connections", 1996 71(8), 51.

4. Lankard, B.A., "Employability- the fifth basic skill", Eric Digest N0.14.Colunbus: Centeron Education and Training for employment. (1990) the Ohio State University (ERIC No.EDO-CE-90104) 
5. Lorraine Dacre Pool, Peter Sewell., "The key to employability: developing a practical model of graduate employability", Centre for Employability, University of Central Lancashire, Preston, UK. Education and Training. Vol. 49, No. 4, 2007.pp. 277-289.

6. National association of Colleges and Employers, "Employers identify the Skills, Qualities of the Ideal candidate", news release, January 15, 2004, downloaded at the NACE Website www.nace.web.org

7. Paulson, K., "Using competencies to connect the workplace and postsecondary education", New Directions for Institutional Research 110, 2001, pp. 41-54

8. Robinson, J.P., "What are employability skills", Employability Skills: from corporate 'wish list' to government policy", Journal of Curriculum Studies, 1998 Vol. 30(2), pp. 143-164.

9. Teichler, "Research on the relationships between higher education and the world of work; past achievements, problems and new challenges", Higher education, 1999, Vol. 38, pp. 169-190.

10. Yorke, M.,"Employability in higher education: what it is - what it is not", Enhancing Student Employability Coordination Team (ESECT), The Higher Education Academy, 2006.

11. [Online] Available: http://www.drrodenglish.blogspot.com

12. [Online] Available: http://www.knowledgecommission.gov. in April 2009

13. [Online] Available: http://www.engsc.ac.uk/er/ employability

14. [Online] Available: http://www.rajivudyogasri.gov.inn 